\author{
Available online at Dakwah: Jurnal Kajian Dakwah dan Kemasyarakatan \\ http://journal.uinjkt.ac.id/index.php/dakwah \\ Dakwah: Jurnal Kajian Dakwah dan Kemasyarakatan, 25 (1), 2021,21-47
}

\title{
Kearifan Penyuluh Islam dalam Pluralitas Agama
}

\author{
M. Lutfi \\ UIN Syarif Hidayatullah Jakarta \\ m.lutfi@uinjkt.ac.id
}

\begin{abstract}
:
"Pluralism" views diversity in a positive-optimistic way by accepting it as a "reality" and doing our best based on that reality. Pluralism does not merely point to the fact that there is pluralism, but also active involvement in that pluralism. Religious and cultural pluralism can be found in everyday life, both at work and on campus as well as in public services and shopping centers. However, a person can only be said to have a "pluralist" nature if he is able to interact positively and tolerantly in this pluralistic environment. In Islam, the reality of plurality is a historical fact, and is recognized as part of human diversity on earth. So that it can be ascertained that, no one is allowed to impose anything on others, including in matters of belief or religion (read, among others: Qs. Al-Baqarah [2]: 256, Qs. AlKafirun [109]: 1-6). But what is needed is the "wisdom" of each religion, so that it gives birth to "tolerance" and "maturity" in practicing religious teachings, or in popular language "to make peace with differences". Religious instructors who have strategic roles and functions in fostering religious life for the community should have that wisdom, which can be used as a strength in responding to the dynamics of religious community life.
\end{abstract}

Keywords: pluralism, religious pluralism, extension

\begin{abstract}
Abstrak
"Pluralisme" memandang kemajemukan secara positif-optimis dengan menerimanya sebagai kenyataan dan berbuat sebaik mungkin berdasarkan
\end{abstract}


kenyataan itu. Pluralisme tidak semata-mata menunjuk pada kenyataan adanya kemajemukan, tetapi juga keterlibatan aktif terhadap kemajemukan tersebut. Pluralisme agama dan budaya dapat dijumpai dalam kehidupan sehari-hari, baik di tempat kerja dan di kampus maupun di tempat pelayanan umum dan pusat-pusat perbelanjaan. Akan tetapi seseorang baru dapat dikatakan memiliki sifat "pluralis" apabila ia mampu berinteraksi secara positif dan toleran dalam lingkungan kemajemukan tersebut. Dalam Islam realitas pluralitas merupakan sesuatu fakta yang menyejarah, dan diakui sebagai bagian dari keanekaragaman manusia di muka bumi. Sehingga bisa dipastikan bahwa, tidak ada seorang pun yang boleh memaksakan sesuatu terhadap orang lain, termasuk dalam masalah keyakinan atau agama (baca antara lain : Qs. Al-Baqarah [2] : 256, Qs. Al-Kafirun [109] : 1-6). Tetapi yang dibutuhkan adalah "kearifan" dari masing-masing pemeluk agama, sehingga melahirkan "toleransi" dan "kedewasaan" dalam mengamalkan ajaran agama, atau dalam bahasa populernya "berdamai dengan perbedaan". Penyuluh agama yang memiliki peran dan fungsi strategis dalam pembinaan kehidupan beragama bagi masyarakat seyogianya mempunyai kearifan itu, yang dapat dijadikan sebagai kekuatan dalam menyikapi dinamika kehidupan masyarakat beragama.

Kata kunci: pluralisme, pluralitas agama, penyuluh

Permalink/DOI: http://doi.org/10.15408/dakwah.v25i1.23186

\section{Pendahuluan}

Adanya kesepakatan dari para pendiri bangsa Indonesia dalam menetapkan semboyan "Bhinneka Tunggal Ika" pada prasasti lambang Negara "Burung Garuda" yang dimaknai "meskipun berbeda-beda tetapi tetap satu" merupakan bangunan isyarat "kearifan bersama" bahwa bangsa dan Negara Indonesia yang terdiri dari beragam etnis, adat istiadat, budaya, dan agama serta mayoritas beragama (berkeyakinan) Islam telah berkomitmen untuk membangun bangsa dan negaranya sejak 17 Agustus 1945 dalam "rumah perbedaan dan keragaman" serta menyatakan siap hidup "berdamai dengan/dalam perbedaan”. Bangunan komitmen ini sekaligus disampaikan kepada dunia bahwa bangsa Indonesia adalah salah satu Negara yang paling "pluralis" di dunia. Indonesia tegak dan hadir dari latar belakang yang sangat beraneka ragam (pluralitas), dan tidak kurang dari sekitar 400 kelompok etnis, suku, bahasa, dan agama yang ada dalam pangkuan Ibu Pertiwi-nya.

Realitas dari komitmen tersebut--setidaknya sejak dipukulnya gendrang reformasi tahun 1998---menjadi fakta baru sejarah bangsa Indonesia bahwa pemikiran dan semangat dari 
keniscayaan "pluralitas dan pluralisme" semakin diakui dan diterima secara luas di masyarakat. Apatahlagi sejak meninggalnya Gus Dur (KH. Abdurrahman Wahid), yang oleh Susilo Bambang Yudoyono (SBY) ketika menjabat Prisiden memberikan julukan kepada Gus Dur sebagai "Bapak Pluralisme", maka hal ini menjadi moment penting bagi para penggiat pemikiran, ajaran, dan paham pluralisme untuk terus memperjuangkan gagasan pluralitas dalam kehidupan berbangsa dan bernegara. Meskipun, lembaga keagamaan Islam seperti Majelis Ulama Indonesia (MUI) sudah mengeluarkan fatwanya tentang haramnya pemahaman pluralisme, dengan alasan pemikiran atau paham tersebut tidak sejalan dan bertentangan dengan ajaran Islam, ${ }^{1}$ sebagai agama mayoritas bangsa Indonesia.

Terlepas dari kapan munculnya, dan siapa yang memulai serta mengusung atau penggiatnya, serta apa tujuan dan targetnya maka ide, pemikiran, gagasan, dan paham pluralisme kiranya memang layak untuk mendapat sorotan publik khususnya di Indonesia, dan lebih khususnya lagi bagi para Penyuluh Agama dalam posisi dan fungsinya sebagai pendamping masyarakat (baca: masyarakat Islam) dalam kehidupan beragama. Sebagai pengayom masyarakat dalam kehidupan sosial keagamaan, maka Penyuluh Agama punya tanggung jawab moril dalam menyikapi berbagai hal yang muncul sebagai bagian dari keragaman pemeluk agama dan berperilaku sesuai keyakinan agama mereka masingmasing. Jika tidak disikapi secara arif dan obyektif, ada kekhawatiran kalau keberagaman paham tersebut dapat mengganggu ketenteraman kehidupan beragama, dan pada gilirannya akan menjadi stigmatis dan problem tersendiri dalam hubungan antar umat beragama. Kehadiran Penyuluh Agama dalam kehidupan beragama di masyarakat diharapkan bisa menjadi soko guru (good father), sehingga mampu menghadirkan rasa nyaman (sefty) ketika terjadi silang pendapat (kegaduhan pemahaman keagamaan), baik intern umat beragama, antar umat beragama, dan umat beragama dengan pemerintah. Untuk itu, pada bagian kunci dari tulisan ini akan menyoroti pluralisme dari sisi wacana tafsir mengenai ayat-ayat yang lazim digunakan ketika membincang ide, pemikiran, gagasan, dan paham pluralisme.

\section{Pluralisme, Pluralitas, dan Pluralisme Agama}

Secara harfiah kata "plural" berasal dari bahasa Latin "plures", yang berarti "beberapa" dengan pemahaman adanya realitas dan implikasi "perbedaan" pada penciptaan alam dan semua isinya. Dan secara filosofis, dipahami bahwa semangat pluralitas hadir dan dibangun dari prinsip "pluralisme" yang berkaitan dengan sikap, pemahaman, dan kesadaran terhadap adanya "kemajemukan" dan "keragaman" sebagai sesuatu "keniscayaan". Jadi, pluralisme yang 
berasal dari kata plural atau plures memiliki pengertian "majemuk", yakni lebih dari satu atau bisa pula berarti "jamak".

Dalam leksikal bahasa Inggris, menurut Anis Malik Thoha (2005: 11), pluralisme berasal dari bahasa Inggris "pluralism" dan mempunyai tiga pengertian, yaitu; a) Pengertian kegerejaan, adalah sebutan untuk orang yang memegang lebih dari satu jabatan dalam struktur kegerejaan, atau memiliki dua jabatan atau lebih secara bersamaan, baik bersifat kegerejaan maupun di luar kegerejaan. b) Pengertian filosofis, merupakan sistem pemikiran yang mengakui adanya landasan pemikiran yang mendasarkan lebih dari satu. Dan ke c) Pengertian sosio-politis, adalah suatu sistem yang mengakui "koeksistensi" keragaman kelompok, baik yang bercorak ras, suku, dan aliran maupun partai dengan tetap menjunjung tinggi aspek-aspek perbedaan di antara kelompok-kelompok tersebut. Maka "pluralism", dalam bahasa Inggris dijelaskan sebagai "In the social sciences, pluralism is a framework of interaction in which groups show sufficient respect and tolerance of each other, that they fruitfully coexist and interact without conflict or assimilation" (Suatu kerangka interaksi yang mana setiap kelompok menampilkan rasa hormat dan toleran satu sama lain, dan berinteraksi tanpa konflik atau berasimilasi/pembauran).

Nurcholish Madjid (almrhm.) yang terkenal dengan pemikiran moderatnya, menjelaskan "pluralisme" sebagai suatu sistem nilai yang memandang secara positif-optimis terhadap "kemajemukan", dengan menerimanya sebagai sebuah "kenyataan/realitas" dan berbuat sebaik mungkin berdasarkan kenyataan itu. ${ }^{2}$ Sedangkan Alwi Shihab, memaparkan pengertian dan sekaligus catatan mengenai pluralisme, yaitu; a) Pluralisme tidak semata-mata menunjuk pada kenyataan adanya kemajemukan, tetapi juga keterlibatan aktif terhadap kenyataan kemajemukan tersebut. b) Pluralisme agama dan budaya dapat dijumpai dalam kehidupan sehari-hari seseorang, baik di tempat kerja dan di kampus maupun di tempat pelayanan umum dan pusat-pusat perbelanjaan. Akan tetapi seseorang baru dapat dikatakan memiliki sifat "pluralis" apabila ia mampu berinteraksi secara positif dan toleran dalam lingkungan kemajemukan tersebut. Dengan demikian, melalu pemahamanan pluralisme tiap pemeluk agama tidak hanya dituntut bisa mengakui dan menerima dari keberadaan dan hak-hak agama suatu komunitas, akan tetapi juga ikut aktif berpartisipasi dan bekerjasama dalam kehidupan antar umat beragama.

Sedangkan "pluralitas" adalah keragaman atau kemajemukan dalam suatu wujud dan bingkai persatuan, keragaman, keunikan, dan parsialitas yang diasumsikan sebagai kenyataan atau realitas yang tak terbantahkan. Dalam berbagai teori ilmu sosial, seperti sosiologi atau psikologi sosial dipahami bahwa, manusia terdiri dari berbagai etnis dan budaya yang saling berbeda dan mengikatkan dirinya antara satu 
dengan yang lainnya. ${ }^{3}$ Semuanya menunjukkan adanya perbedaan, keragaman, dan keunikan namun tetap dalam persatuan. Perbedaan-perbedaan individu melebur ke dalam satu ikatan sosial, keanekaan suku-suku terangkum menjadi satu bangsa dan masyarakat dunia. ${ }^{4}$ Keseluruhan dan kasatuan parsialitas individu-individu itu merupakan bagian dari kenyataan pluralitas, dan pluralitas sesungguhnya wujud terbesar dari bagian-bagian parsialitas tersebut. Sehingga dalam teori "psikologi sosial" diberikan formulasi bahwa kegiatan-kegiatan manusia atau individu ada yang bersifat individual, ada yang bersifat sosial, dan kegiatankegiatan yang bersifat berketuhanan. Maka secara hakiki manusia sekaligus merupakan makhluk individual, makhluk sosial, dan makhluk berketuhanan. 5

Sebagai makhluk individual, manusia merupakan suatu keseluruhan yang tak dapat dibagi-bagi, asal kata individu berarti "tidak dapat dibagibagi". ${ }^{6}$ Segi utama lainnya ialah secara hakiki manusia sebagai makhluk sosial, bahwa sejak ia dilahirkan manusia membutuhkan pergaulan dengan orangorang lain untuk memenuhi kebutuhankebutuhan biologisnya; makanan, minuman, dan lain-lain. Dan sekaligus kebutuhan-kebutuhan psikologisnya; kasih sayang, perhatian, penghargaan, dan lain-lain. ${ }^{7}$ Kemudian segi utama lainnya ialah manusia merupakan makhluk berketuhanan. Meskipun secara empiris-eksperimental Tuhan sukar dibuktikan tidak berarti Tuhan tidak ada, boleh jadi bagi mereka yang belum sadar akan segi kemanusiaan mereka sebagai makhluk yang berketuhanan, maka akan sukar pula menerima atau mengakui hakikatnya dari segi ketiga kemanusiaan itu. ${ }^{8}$

Tetapi disadari atau tidak, dan diakui atau tidak orang "atheis" yang belum sadar akan hal ini pun tanpa disadarinya sebenarnya ia sudah berketuhanan pula, tetapi dalam bentuk pertuhanan benda-benda, orang-orang, ataupun gagasan-gagasan tertentu yang bukan Tuhan Yang Maha Esa (TYME). Misalnya suatu bentuk pertuhanan manusia modern ialah pertuhanan kepada "aliran berfikir materialisme", baik dalam bentuk anggapan maupun dalam perbuatannya. ${ }^{9}$ Dalam pada itu mereka, dengan sadar atau tidak, sudah menyalahgunakan segi berketuhanannya, yang sebenarnya tertuju kepada Tuhan Yang Maha Esa (TYME), Pencipta alam semesta, langit, bumi, dan semuanya yang ada di dalam universum ini. Yakni "penyelewengan" sehingga yang disembahnya bukan lagi Tuhan Yang Maha Esa (TYME), melainkan ciptaannya sendiri. Atau dalam istilah Muhammad Abduh dalam "Risalah Tauhid", mereka telah "memberhalakan" (menuhankan) segala sesuatu yang ada pada tubuh mereka; pikiran, pemahaman, pendengaran, penglihatan, dan lain-lain. Dan juga "memberhalakan" apa-apa yang mereka miliki yang ada disekitarnya. ${ }^{10}$ Meskipun Abduh menggunakan istilah "memberhalakan" sesuatu selain Tuhan Yang Maha Esa, hal ini tidak menafikan hakikat dari nilai "berketuhanan" yang 
tetap ada pada setiap manusia. Maka jiwa, nilai, dan hakikat berketuhanan itu yang kemudian diakui sebagai bagianbagian dari parsialitas yang pada gilirannya menjadi wujud besar dari pluralitas agama dan pluralisme beragama.

Pluralisme dalam kenyataannya seringkali diidentikan dengan paham agama. Maka pluralisme agama merupakan suatu yang agung bagi masyarakat barat yang dijadikan bingkai dalam tatanan kehidupan sekulerisme. Sehingga pluralisme agama dimaknai sebagai konsep yang mempunyai makna yang luas, yakni berkaitan dengan "penerimaan" terhadap agama-agama yang berbeda dan dipergunakan dalam cara yang berlain-lainan pula. Ada beberapa ide dan pemikiran yang menjadi diskursus dan bahkan mungkin perdebatan dalam kajian pluralisme agama, yaitu:

a. Pluralisme agama (religious pluralism) adalah di antara ide yang diusung oleh orang-orang yang berpemahaman liberal. Trend pemikiran yang dibangun di atas dasar kebebasan berkeyakinan ini telah melabrak salah satu pilar terpenting dalam kehidupan beragama; yaitu tentang klaim kebenaran (truth claim) pada setiap agama yang diyakini pemeluknya. Pandangan ini menyoroti bahwa, secara hakiki ajaran pluralisme agama merupakan "agama baru" yang mencoba meruntuhkan nilai-nilai fundamental agama-agama, termasuk Islam. ${ }^{11}$ b. Pluralisme adalah sebuah asumsi yang meletakkan kebenaran agama-agama sebagai "kebenaran yang relatif", dan menempatkan agama-agama pada posisi setara, apapun jenis agamanya. Artinya, pluralisme agama meyakini bahwa semua agama adalah "jalanjalan yang sah menuju Tuhan yang sama”. Dengan kata lain, paham ini menyatakan bahwa agama adalah "persepsi manusia yang relatif terhadap Tuhan yang mutlak, sehingga---karena kerelatifannya--maka seluruh agama tidak boleh mengklaim atau meyakini bahwa agamanya yang "lebih benar" dari agama lain, atau meyakini hanya agamanya yang benar". ${ }^{12}$

c. Sebagai pandangan dunia yang menyatakan bahwa agama seseorang bukanlah sumber satu-satunya yang eksklusif bagi kebenaran, dan dengan demikian di dalam agama-agama lain pun dapat ditemukan, setidaktidaknya suatu kebenaran dan nilainilai yang benar. ${ }^{13}$

d. Sebagai penerimaan atas konsep bahwa dua atau lebih agama yang sama-sama memiliki klaim-klaim kebenaran yang eksklusif sama-sama sahih. Pendapat ini seringkali menekankan pada aspek-aspek bersama yang terdapat dalam agamaagama. Kadang-kadang juga digunakan sebagai sinonim untuk "ekumenisme", yang suatu upaya untuk mempromosikan suatu tingkatan kesatuan, kerjasama, dan penanaman pemahaman yang lebih baik antar agama-agama atau 
berbagai dominasi dalam suatu agama. Dan bahkan lazim pula dijadikan sebagai sinonim dalam mewujudkan "wilayah tawar" untuk toleransi agama yang merupakan prasyarat untuk ko-eksistensi harmonis antara berbagai pemeluk agama ataupun denominasi yang berbeda-beda. ${ }^{14}$

Sebagai lembaga keagamaan yang berkepentingan dan berkontribusi secara moril terhadap keharmonian masyarakat beragama di Indonesia, khususnya umat Islam, maka Majelis Ulama Indonesia (MUI) sudah mengeluarkan fatwanya tentang definisi apa yang dimaksud dengan "Pluralitas Agama" dan "Pluralisme Agama". Pluralitas agama adalah sebuah kenyataan bahwa di Negara atau di daerah tertentu terdapat pemeluk agama yang hidup secara berdampingan, maka menjadi suatu keniscayaan bagi umat Islam untuk hidup berdampingan dengan pemeluk agama lain. Seorang muslim mengakui bahwa di sekelilingnya ada pemeluk agama lain selain Islam, akan tetapi pengakuan tersebut terbatas pada keberagaman agama, bukan pada kebenaran agama lain. Sementara itu definisi pluralisme agama adalah suatu paham yang mengajarkan semua agama sama, dan kebenarannya bersifat relatif. Karenanya, setiap pemeluk agama tidak boleh mengklaim bahwa agamanya yang benar sedangkan agama yang lain salah, serta mengajarkan bahwa semua pemeluk agama akan masuk surga. Pluralisme kerap dipadankan dengan inklusifisme yang dua-duanya samasama berbahaya. ${ }^{15}$

Dengan demikian semakin jelas bahwa secara sederhana pluralisme, pluralitas, dan pluralisme agama dapat diartikan sebagai paham yang mentoleransi adanya keragaman atau kemajemukan pemikiran, peradaban, agama, dan budaya. Bahkan bukan hanya mentoleransi adanya keragaman pemahaman tersebut, tetapi juga mengakui kebenaran masing-masing pemahaman agama setidaknya menurut logika pengikutnya. Dengan kata lain, pluralisme agama merupakan suatu paham yang mengajarkan bahwa semua agama adalah sama, dan karenanya kebenaran setiap agama adalah relatif. Maka setiap pemeluk agama tidak boleh mengklaim bahwa hanya agamanya saja yang benar sedangkan agama yang lain salah.

Pluralisme agama pun mengajarkan bahwa semua pemeluk agama akan masuk dan hidup berdampingan di surga. Sementara "pluralitas agama" merupakan sebuah kenyataan bahwa di Negara atau daerah tertentu terdapat berbagai pemeluk agama yang hidup secara berdampingan, dan diakui keberadaannya sehingga satu sama lain bisa berinteraksi dan bekerjasama dalam urusan muamalah, serta masing-masing umat beragama memiliki hak yang sama dalam menjalankan ibadahnya menurut keyakinan dan kepercayaan masingmasing. Toleransi hidup beragama seperti inilah yang sudah terbangun dalam lingkungan masyarakat beragama 
di Indonesia, yakni adanya penerimaan bersama mengenai kenyataan pluralitas agama, namun tidak semua menerima pluralisme agama.

\section{Latar Belakang, Argumen, dan} Kontroversi Pluralisme Agama

Terlepas dari pemikiran setuju atau tidak, maka fakta sejarah dan realitas menunjukkan bahwa yang menjadi latar belakang munculnya ide, pemikiran, gerakan, dan paham pluralisme disinyalir sebagai bentuk reaksi dari tumbuhnya klaim kebenaran oleh masing-masing kelompok agama terhadap pemikiran dan kebenaran agamanya sendiri. Bahkan ada perspektif yang menyatakan bahwa "persoalan klaim kebenaran" inilah yang dianggap sebagai pemicu lahirnya pluralisme dan radikalisasi agama, perang dan penindasan atas nama agama di berbagai belahan dunia. ${ }^{16}$ Sehingga ada tawaran kosmopolis bahwa, konflik horizontal antar pemeluk agama hanya akan selesai jika masing-masing agama tidak menganggap bahwa ajaran agama mereka saja yang paling benar, dan agama yang lainnya salah. Itulah tujuan akhir dan agenda besar dari gerakan pluralisme, yaitu untuk menghilangkan keyakinan akan klaim kebenaran agama dan paham yang dianut, sedangkan agama dan paham yang di luar agamanya salah.

Pada dasarnya klaim kebenaran di internal masing-masing umat beragama biasa diajarkan, agar setiap umat beragama dapat dengan sungguhsungguh meyakini ideologi atau pun 'aqidah agamanya, serta dengan sepenuh hati (kaffah) mengamalkan ritual-ritual dari perintah atau pesan doktrin dari kitab suci agamanya. Namun, boleh jadi yang dimaksudkan oleh gerakan pluralisme agama itu adalah bagaimana supaya keyakinan terhadap ideologi suatu agama dan ketekunan dalam mengamalkan perintahnya tidak menimbulkan "gesekan, kebencian, permusuhan, dan perang" dengan umat agama lain yang berada di luar agamanya, yang mana hal itu dipicu oleh jiwa "ego sentries" bahwa agamanya saja yang benar dan sah, dan yang lainnya salah atau sesat.

Padahal keyakinan universal mengajarkan bahwa, setiap orang yang sudah mengakui dirinya sebagai makhluk yang berketuhanan, lalu sudah berusaha untuk mencari hakikat ketuhanan itu beradasarkan keyakinan dan kerja kerasnya maka patut diapresiasi bahwa orang tersebut sudah berupaya untuk menemukan kebenaran. ${ }^{17}$ Sehingga, sebagai sebuah proses, dia sudah berusaha mengakui dan mencari Tuhannya, meskipun jalan yang ia lalui berbeda-beda. Dan secara kosmos, tidak ada seorangpun yang bisa merencanakan apalagi memastikan bahwa ia akan lahir dengan membawa agama tertentu sebagai klaim kebenaran. Sebut saja, apakah ia akan lahir beragama Yahudi, Nasrani, Majusi, Sabi'i, Konghucu dan ataupun beragama Islam, maka yang tahu hanya sang Penciptanya.

Sebagai wacana berfikir dalam konteks dan argumentasi pluralisme 
agama ini, menarik bila diasosiasikan dengan logika dari seorang Murtadha Muthahhari ketika ditanya tentang "keadilan Tuhan" kalau dikaitkan dengan "perbuatan baik non-Muslim". Apakah perbuatan baik seorang non-Muslim itu diterima atau tidak? Jika diterima, maka seorang Muslim dan non-Muslim menjadi "tidak berbeda lagi". Demikian pula apabila kita berasumsi sama terhadap seorang non-Muslim atau tidak beragama sama sekali (atheis), namun ia tidak merugikan orang lain. Dan sekiranya tidak diterima, bahkan perbuatannya itu laksana debu yang bertebaran, tidak mendapat pahala dan balasan dari Allah, maka bagaimana hal itu akan sejalan dengan "keadilan Tuhan?"18

Kemudian, pertanyaan berikutnya yang dimunculkan ialah; "Apakah agama yang diterima Allah itu hanya Islam, ataukah ada agama lain yang diterima di sisi-Nya?”. Dengan kata lain, apakah yang diwajibkan kepada seseorang itu hanyalah beragama dengan agama tertentu, paling tidak agama tersebut dinisbatkan kepada nabi Allah, dan tidak ada perbedaan apakah agama tersebut "Islam, Kristen, bahkan Majusi?” Atau, apakah pada setiap zaman hanya terdapat satu agama haikiki, tidak ada yang lain?'19 Umumnya untuk menjawab pertanyaan tersebut, umat Islam secara "mutawatir" menyatakan bahwa agama yang diterma Allah hanya "Islam" dan sekaligus sebagai agama hakiki sepanjang zaman. Dan argument yang digunakan ialah pemahaman dan tafsir surat Ali Imran
(3) ayat 85; "Barangsiapa yang mencari agama selain agama Islam, maka sekali-kali tidaklah akan diterima (agama itu) darinya, dan di akhirat ia termasuk orang-orang yang merugi”. (Qs. $3: 85$ ). ${ }^{20}$

Bila yang dimaksudkan dengan "Islam" dalam ayat di atas adalah berserah diri (taslim) kepada Allah, bukan kepada agama terakhir bagi manusia, maka jawabnya ialah: Benar, bahwa Islam itu artinya berserah diri (taslim) dan agama Islam tak lain adalah agama "taslim". Hanya saja hakikat "taslim" pada setiap zaman itu mengambil bentuk tertentu, dan bentuknya pada zaman terakhir adalah agama yang dibawa oleh Nabi penutup Saw. Karenanya, kata "Islam" itu sendiri hanya sesuai dengan agama Islam itu saja. Dengan kata lain, berserah diri (taslim) kepada Allah, pada dasarnya mengharuskan diterimanya seluruh perintah Allah. Jelasnya, orang tersebut harus mengamalkan perintah-perintahNya, dan perintah-perintah-Nya yang terakhir, adalah agama yang dibawa oleh Rasulullah Saw. ${ }^{21}$

Kemudian argumentasi lainnya yang digunakan dalam skema pluralisme agama adalah mengumpamakan beragama dengan "tiga orang buta" yang diminta menjelaskan tentang bentuk gajah. Ketiga orang buta itu diminta untuk memegang gajah, ada yang memegang telinganya, ada yang memegang kakinya, dan ada pula yang memegang belalainya. Ketika masingmasingnya sudah memegang gajah sesuai dengan posisinya, lalu diminta 
untuk menjelaskan gajah itu seperti apa? Maka satu sama lain bercerita; yang memegang telinga berkata bahwa gajah itu seperti kipas yang lebar dan kaku, yang memegang kaki mengatakan bahwa gajah itu seperti pohon besar yang kokoh, dan yang memegang belalai mengatakan bahwa gajah itu seperti pipa.

Aragumen berupa analogi cerita tersebut boleh jadi benar bila antar umat beragama meyakini dan mengamalkan agamanya tidak disertai pengetahuan yang benar (as-sufaha'), alias bagaikan orang buta dengan agamanya, sehingga akan mudah tersulut konflik disebabkan kurangnya ilmu ('adwan bi ghairi ilm). Seperti firman Allah Swt.: "Dan janganlah kamu memaki sesembahan yang mereka sembah selain Allah, karena mereka nanti akan memaki Allah dengan melampaui batas tanpa dasar pengetahuan. Demikianlah, Kami jadikan setiap umat menganggap baik pekerjaan mereka. Kemudian kepada Tuhan tempat kembali mereka, lalu Dia akan memberitahukan kepada mereka apa yang telah mereka kerjakan”. (Qs. 6 : 108). ${ }^{22}$

Kontroversi masalah pluralisme dan pluralitas agama, khususnya di Indonesia hingga kini masih berlanjut; tetap ada yang pro dan kontra. Ada yang sangat apriori dengan gerakan pluralisme agama, dan dengan sinis menyatakan bahwa gerakan ini didalangi oleh gerakan Jaringan Islam Liberal (JIL) beserta antek-anteknya, dan telah memproklamirkan kelompok mereka sebagai sebuah aliran "oposisi” dalam
Islam. Ada tuduhan bahwa JIL sangat gencar sekali mengadu domba antar umat Islam, dan antar umat Islam dengan agama lainnya, bahkan mereka mengusung jargon tuntutan "persamaan hak antar agama" yang dampaknya meresahkan umat Islam lainnya. Disinyalir, keresahan inilah kemudian yang mendesak MUI untuk mengeluarkan fatwa tentang keberadaan pluralisme, liberalisme, dan sekulerisme agama di Indonesia.

Pengamat liberalisme Adian Husaini, dengan tegas menyatakan; jika ada yang mengatakan bahwa "pluralisme" itu bisa menerima kemajemukan perbedaan agama masyarakat, pada dasarnya pernyataan itu bohong. Karena "pluralisme” justru memaksa orang untuk ragu pada agamanya sendiri. Bahkan, gara-gara "pluralisme"-lah orang jadi tidak beragama dan mendekat pada konsep atheisme. Jadi, "pluralisme" menurut Adian merupakan sebuah "isme" yang berbahaya dan bahkan dapat memecah belah satu keluarga dengan berbagai macam pandangan terhadap sebuah agama. Sehingga, dalam satu keluarga bisa jadi akan ditemukan menganut berbagai macam agama, atau bisa disebut keluarga "gado-gado". ${ }^{23}$

Namun, sampai saat ini di tengah-tengah masyarakat masih ditemukan perbedaan persepsi dalam mengartikan dan memahami istilah "pluralitas" dan "pluralisme". Sehingga, seakan-akan disinyalir bahwa umat Islam menolak "keragaman agama" yang ada di Indonesia, padahal dalam 
realitasnya tidak benar seperti itu. Karenanya, perlu disosialisasikan secara baik kepada semua lapisan umat Islam agar masyarakat semakin terbiasa dan memahami secara utuh maksud dari dua istilah; pluralitas dan pluralisme. Dalam pada ini di bagian akhir fatwanya, MUI tidak lupa mengingatkan bagi masyarakat muslim yang tinggal bersama pemeluk agama lain (pluralitas agama), bahwa dalam masalah sosial yang tidak berkaitan dengan persoalan 'aqidah dan ibadah umat bersikap "inklusif", dalam arti tetap melakukan pergaulan sosial dengan pemeluk agama lain sepanjang tidak saling merugikan. ${ }^{24}$

Sejak era orde baru, beberapa cendikiawan muslim Indonesia telah terlibat dalam sejumlah forum diskursus tentang "Islam dan Pluralisme". Hal ini didasari oleh pandangan dan pemikiran bahwa "Islam merupakan agama kemanusiaan (fithri)", yang berarti citacitanya sejajar dengan cita-cita kemanusiaan universal. Nurcholis Madjid misalnya, berpendapat bahwa cita-cita keislaman sejalan dengan citacita manusia Indonesia pada umumnya. Ini adalah salah satu pokok ajaran Islam, yang karenanya sistem politik yang diterapkan di Indonesia sebaiknya sistem yang tidak hanya baik untuk umat Islam, akan tetapi juga membawa kebaikan untuk semua anggota masyarakat. ${ }^{25}$ Dengan kata lain, diperlukan suatu sistem yang menguntungkan semua pihak, termasuk mereka yang nonMuslim. Menurut Cak Nur, hal ini sudah sejalan dengan watak atau karakteristik inklusif Islam Indonesia, dan juga sudah dapat dukungan dalam sejarah awal Islam, khususnya pada era Madinah. ${ }^{26}$ Perlu kesadaran bersama bahwa Indonesia sudah dilahirkan oleh sejarah yang niscaya dengan keragaman atau kemajemukan dan sangat pluralistik; etnis, adat istiadat, budaya, dan agama. Realitas sudah menunjukkan bahwa selain Islam, hampir semua agama khususnya agama-agama besar sudah dapat berkembang subur dan mewakili aspirasinya di Indonesia, bahkan jauh sebelum masa kemerdekaan. Oleh karenanya, pilihan yang terbaik ialah mewujudkan pola toleransi antar umat beragama dan mungkin menjadi sangat penting, karena Islam sudah teruji kemampuannya dalam membangun toleransi dan pluralitas agama di banyak Negara dunia.

Kemudian KH. Abdurrahman Wahid, yang akrab disapa Gus Dur dan sekaligus dijuluki sebagai "Bapak Pluralisme" setidaknya oleh Presiden SBY, juga banyak memberikan perspektif mengenai hubungan antara "Islam dengan pluralisme" dalam konteks manifestasi universalisme dalam "kosmopolitanisme ajaran Islam". Menurut Gus Dur, Islam merupakan agama yang sempurna dalam menampilkan universalisme. Hal ini dibuktikannya dengan adanya lima jaminan dasar (asasi) yang diberikan Islam kepada warga masyarakat (tidak hanya sesama umat Islam), baik secara perorangan maupun kelompok, yaitu; 1) Keselamatan fisik warga Negara, 2) Keselamatan keyakinan agama masingmasing, 3) Keselamatan keluarga dan 
keturunan, 4) Keselamatan harta benda dan milik pribadi, dan 5) Keselamatan profesi. ${ }^{27}$ Melalui jaminan itu, diharapkan cita-cita untuk menjadikan Islam dan umat Islam sebagai "pemberi warna tunggal” bagi kehidupan berbangsa dan masyarakat Indonesia akan terwujud. Maka dengan itu pula format perjuangan Islam pada akhirnya menjadi partisipasi penuh dalam upaya mewujudkan Indonesia yang kuat, demokrtais, dan berkeadilan, serta memposisikan Islam sebagai kekuatan integrativ dalam kehidupan berbangsa.

\section{Wacana Tafsir tentang Pluralisme (Umat Lain)}

Setelah memahami makna pluralitas agama dan pluralisme agama, serta dilengkapi dengan fatwa Majelis Ulama Indonesia (MUI)mengenai kedua istilah dimaksud, bahkan dalam fatwanya nomor 7/Munas VII/MUI/II/2005 tertanggal 29 Juli 2005 sudah menetapkan bahwa "pluralisme agama adalah paham yang bertentangan dengan ajaran Islam”. Namun, tulisan ini tidak bermaksud untuk menjadikan fatwa MUI itu sebagai kesimpulan "wacana diskusi tafsir tentang ayat-ayat yang mengandung isyarat pluralisme", dan sekaligus ayatayat dimaksud lazim dijadikan argumentasi dalam peniscayaan pluralitas dan pluralisme agama. Akan tetapi, fatwa dan berbagai pikiran yang sudah dipaparkan sebelumnya akan dijadikan sebagai pokok pikiran dan landasan empiris dalam menelusuri "wacana kritik tafsir" tentang pluralisme, khususnya ketika menimbang dan memposisikan umat dan agama lain di luar Islam; Sebagai rival atau musuhkah? Atau sebagai sahabat, mitra, dan saudara-saudara kemanusiaan yang entitasnya sudah niscaya sejak awal peradaban manusia di bumi?

Dan keberadaan mereka samasama mencari kebenaran jalan Tuhan melalui cara yang berbeda-beda; apakah harus saling benci dan menindas bila tidak saling merugikan? Terlepas dari posisi agama manapun anda berada sekarang; Islam, Kristen, Hinda, Budha; Yahudi, Majusi, dan lain-lain. Apakah dengan cara-cara saling benci, bermusuhan, menindas, perang, dan membunuh itu misalnya ada para pihak yang merasa menang dan beruntung? Maka gagasan, ide, pemikiran, dan pendekatan agar pluralitas agama dan pluralisme agama sebagai sebuah pilihan atau alternatif patut pula dijadikan opsi pertimbangan dalam bagian diskusi studi-studi Islam. Atau kalau tidak sependapat, boleh diberikan usulan istilah yang lain; intinya bagaimana caranya agar keragaman dan kemajemukan etnis, budaya, adat istiadat, dan agama ini bisa hidup dalam satu atap dengan damai dan tenteram.

Dalam studi Islam, khususnya dalam bidang kajian "ilmu al-Qur'an dan Tafsir”, maka ranah dari kontent yang dimunculkan ialah wacana tafsir tentang pluralitas ataupun pluralisme. Ada beberapa ayat yang lazim dijadikan bahan "diskursus" dalam memaknai pluralitas dan pluralisme, lalu dikaitkan dengan keberadaan agama-agama yang 
ada di dunia, khususnya agama samawi. Ayat-ayat yang dimaksudkan adalah sebagai berikut:

Qs. Al-Baqarah (2) ayat 256, yang artinya: "Tidak ada paksaan dalam (menganut) agama (Islam),... ${ }^{28}$

Dalam menafsirkan ayat tersebut, kelompok yang pro-pluralisme menguraikan atau menafsirkan bahwa "tidak ada paksaan dalam beragama (untuk mengikuti Islam)" berarti pengakuan kepada agama yang lain juga sama. Kelompok yang kontra-pluralisme membantah, pemahaman yang demikian itu bukan pemahaman yang benar. Untuk lebih memahami makna "tidak ada paksaan...” ini maka satu ayat penuh harus dipahami secara utuh. Lanjutan ayat tersebut adalah, "sesungguhnya telah jelas jalan yang benar daripada jalan yang sesat. Karena itu barangsiapa yang ingkar kepada "thaghut" dan beriman kepada Allah, maka sesungguhnya ia telah berpegang kepada "buhul tali" yang kuat dan tidak akan putus. Dan Allah Maha Mendengar lagi Maha Mengetahui”. Point utama dalam penafsiran ayat ini adalah; karena tidak ada paksaan boleh jadi agama selain Islam juga mendapat posisi yang sama, masalah benar atau sesat dikembalikan kepada otoritas Allah Tuhan Yang Maha Esa.

Ibnu Katsir menafsirkan ayat tersebut, maksudnya, janganlah kamu memaksa seorang pun untuk "memasuki agama Islam”, karena agama Islam itu sudah jelas dan terang. Dalil-dalil dari argumentasinya sudah nyata, sehingga seseorang tidak perlu dipaksa supaya masuk agama Islam. Namun, orang yang ditunjukkan kepada Islam, dilapangkan hatinya, dan disinari mata hatinya oleh Allah, maka ia akan masuk ke dalamnya secara terang benderang. Adapun orang yang hatinya dibutakan Allah ${ }^{29}$ dan dikunci mati oleh Allah, maka tidaklah berguna memaksanya untuk memasuki Islam. ${ }^{30} \mathrm{Jadi}$, pointnya tidak boleh ada pemaksaan bagi siapapun untuk menerima Islam atau belum sejalan dengan Islam karena dalil dan hujjahnya sudah terang benderang.

Kemudian, Al-Maraghi ketika menafsirkan ayat tersebut menjelaskan, "tidak ada paksaan dalam memasuki agama" karena iman harus dibarengi dengan perasaan taat dan tunduk. Hal ini tentunya, tidak bisa terwujud dengan cara memaksa, tetapi hanya mungkin melalui hujjah atau argumentasi. Menurut Al-Maraghi, ayat ini kiranya cukup sebagai hujjah di hadapan orangorang yang sengaja atau tidak memusuhi Islam, bahkan mungkin orang-orang Islam sendiri yang mempunyai prasangka bahwa Islam tidak bisa tegak melainkan dengan pedang (kekerasan) sebagai penopangnya. ${ }^{31}$ Menurut AlMaraghi, larangan untuk tidak adanya paksaan dalam beragama karena mengikuti suatu keyakinan (keimanan) harus disertai dengan perasaan, hati, dan jiwa yang tunduk (taslim). Ini berlaku untuk semua agama yang mengakui adanya Tuhan, bila pesan ini dipahami oleh semua penganut agama maka tidak akan terjadi paham radikalisme dalam menjalankan agamanya. 
Selanjutnya, Quraish Shihab dalam "Tafsir Misbah" menjelaskan beberapa makna dan pemahaman dalam tafsir ayat tersebut, yaitu:

1) Mengapa ada paksaan, padahal Dia (Allah) tidak membutuhkan sesuatu;

2) Mengapa ada paksaan, padahal sekiranya Allah menghendaki, niscaya kamu dijadikan-Nya satu umat (saja) (Qs. Al-Ma'idah [5]: 48);

3) Perlu dicatat, bahwa yang dimaksud dengan tidak ada paksaan dalam menganut agama adalah menganut akidahnya. Ini berarti jika seseorang telah memilih satu akidah, katakan saja akidah Islam, maka ia terikat dengan tuntunan-tuntunannya, dia berkewajiban melaksanakan perintah-perintahnya. Dan tidak boleh berkata, "Allah telah memberi saya kebebasan untuk shalat atau tidak, berzina atau menikah". Karena bila dia telah menerima akidahnya, maka dia harus melaksanakan tuntunannya.

4) Tidak ada paksaan dalam menganut keyakinan agama; Allah menghendaki agar setiap orang merasakan kedamaian. Agama-Nya dinamai Islam, yakni damai. Kedamaian tidak dapat diraih kalau jiwa tidak damai. Paksaan menyebabkan jiwa tidak damai, karena itu tidak ada paksaan dalam menganut keyakinan agama Islam. ${ }^{32}$ Quraish Shihab mengingatkan bahwa, beragama pada dasarnya ingin menemukan dan meraih kedamaian, dan hanya bisa didapatkan dengan jiwa yang damai (muslim), dan bukan dengan cara paksaan.Bahkan, bila ingin sama dan seragam semuanya Allah bisa saja hanya menciptakan satu umat, sehingga tidak ada yang berbeda satu sama lain, berarti Allah sebagai Pencipta telah meniscayakan adanya perbedaan tersebut.

Qs. Al-Baqarah (2) ayat 62, yang diterjemahkan, "Sesungguhnya orangorang yang beriman, orang-orang Yahudi, orang-orang Nasrani, dan orang-orang Sabiin, siapa saja (di antara mereka) yang beriman kepada Allah dan hari akhir, dan melakukan kebaikan, mereka mendapat pahala dari Tuhannya, tidak ada rasa takut pada mereka, dan mereka tidak bersedih hati”.33 Para penggiat atau yang pro gerakan pluralisme menyatakan ayat ini merupakan argumentasi naqliyyah dan qath'iyy untuk menyebutkan bahwa semua agama (Islam, Yahudi, Nasrani, dan Sabi'in) pada dasarnya menyembah Tuhan yang sama, meskipun cara penyembahannya berbeda-beda. Jika mereka melakukan kebaikan, maka masing-masingnya akan mendapatkan pahala dari Tuhannya, tidak perlu merasa takut dan bersedih hati.

Dalam tafsirnya, Quraish Shihab menjelaskan melalui ayat tersebut Allah memberi jalan keluar sekaligus ketenangan kepada mereka yang bermaksud memperbaiki diri. Ini sejalan dengan kemurahan Allah yang selalu membuka pintu bagi hamba-hamba-Nya yang insaf. Kepada mereka disampaikan 
bahwa jalan guna meraih ridha Allah bagi mereka serta bagi umat-umat lain, tidak lain kecuali iman kepada Allah dan hari kemudian serta beramal shaleh. Karena itu ditegaskannya bahwa, Sesungguhnya orang yang beriman, yakni yang mengaku beriman kepada Nabi Muhammad Saw., orang-orang Yahudi, yang mengaku beriman kepada Nabi Musa as., dan orang-orang Nasrani yang mengaku beriman kepada Nabi Isa as., dan orang-orang Shabiin, kaum musyrik atau penganut agama dan kepercayaan lain, siapa saja di antara mereka yang benar-benar beriman kepada Allah dan hari kemudian sebagaimana dan sesuai dengan segala unsur yang diajarkan Allah melalui para nabi serta beramal shaleh, yakni yang bermanfaat dan sesuai dengan nilai-nilai yang ditetapkan Allah, maka untuk mereka pahala amal-amal shaleh mereka yang tercurah di dunia ini dan tersimpan hingga di akhirat nanti di sisi Tuhan Pemelihara dan Pembimbing mereka, serta atas kemurahan-Nya; tidak ada kekhawatiran terhadap mereka menyangkut sesuatu apapun yang akan datang, dan tidak pula mereka bersedih hati menyangkut sesuatu yang telah terjadi.34 Point utamanya ialah, bahwa siapa saja yang mengimani Allah, Muhammad, Musa, dan Isa berdasarkan ajaran yang benar maka setiap kebaikannya akan mendapat pahala dari Tuhan di dunia dan akhirat.

Dalam kesimpulan tafsirnya tentang ayat tersebut, Al-Maraghi menyatakan sesungguhnya orang-orang yang beriman apabila memegang teguh keimanannya dan tidak pernah berganti keimanan, kemudian orang-orang Yahudi dan Nasrani dan orang-orang Sabi'in, apabila mereka beriman kepada Muhammad Saw. dan beriman kepada apa yang didatangkan kepadanya, serta beriman kepada hari akhir, mau beramal shaleh dan tidak mau merubah pendiriannya sampai mereka mati, maka mereka akan mendapatkan pahala di sisi Allah sebagai imbalan atas amal shalehnya. Selamanya mereka tidak akan merasa khawatir, dan tidak akan kesusahan. 35 Dengan demikian, umat Islam, Yahudi, Nasrani, dan Sabi'in memiliki peluang yang sama bila mereka beragama sebagaimana yang dimaksudkan ayat tersebut.

Sementara itu, Ibnu Katsir dalam menafsirkan ayat itu menjelaskan pada dua unsur subyek yang dipisahkan, yaitu:

1) Pertama; Sesungguhnya orangorang mukmin, mereka adalah umat Muhammad Saw. Umat ini disebut "mukminin"36 karena keimanan mereka besar dan keyakinan mereka kuat serta karena mereka beriman kepada seluruh nabi yang terdahulu dan kepada hal-hal ghaib yang akan terjadi.

2) Kedua; Dan orang-orang Yahudi, Nasrani, Shabiin, dan siapa saja yang beriman kepada Allah dan hari akhir, yakni orang yang beriman dari kalangan Yahudi, Nasrani, dan Shabi'in, 37 baik mereka itu tergolong kepada umat terdahulu---yaitu orang-orang yang beriman kepada para nabi dan pada kitabnya tanpa mengubah dan menggantinya, 
sedang mereka mati dalam kondisi tetap demikian---maupun orang yang hidup hingga zaman Rasulullah Saw., seperti Abdullah bin Salam, anNajasyi, Salman al-Farisi, dan mereka beriman kepada Allah, RasulNya, dan mengerjakan amal shaleh. Maka bagi mereka pahala pada sisi Tuhan mereka, serta mereka tidak usah khawatir dan bersedih hati karena Allah tidak menerima amal seseorang kecuali amal yang selaras dengan syariat Nabi-Nya Saw. ${ }^{38}$

Qs. An-Nisa' (4) ayat 131, yang terjemahannya ialah, "Dan milik Allahlah apa yang ada di langit dan apa yang ada di bumi, dan sungguh, Kami telah memerintahkan kepada orang yang diberi kitab suci (ahli kitab) sebelum dan (juga) kepadamu agar bertakwa kepada Allah. Tetapi jika kamu ingkar maka (ketahuilah), milik Allah-lah apa yang ada di langit dan apa yang ada di bumi, dan Allah Mahakaya, Maha Terpuji”. ${ }^{39}$

Al-Maraghi menafsirkannya bahwa, a) baik dari segi penciptaan maupun dari segi kerajaan segala apa yang ada di langit dan di bumi, hanyalah kepunyaan Allah, karena hanya Dia-lah yang mengatur seluruh alam semesta. Oleh karena itu, tidak ada uzur bagi-Nya untuk membuat orang kaya setelah miskin dan membuat orang bersuka cita setelah sedih, dan lain sebagainya, yang menunjukkan betapa agung kekuasaanNya, dan betapa sempurna kemurahan seta kebaikan-Nya.40b) Kami telah memerintahkan kepada umat-umat sebelum kalian seperti umat Yahudi,
Nasrani, dan umat-umat lain, sebagaimana Kami telah memerintahkan kepada kalian supaya bertakwa kepada Allah di dalam menegakkan sunnahsunnah dan syari'at-Nya. Sebab dengan menegakkan sunnah-sunnah-Nya, niscaya pengetahuan kalian akan meningkat; dan dengan menegakkan syari'at-Nya, diri kalian akan bersih, segala maslahat keagamaan dan keduniaan kalian akan teratur. c) Jika kalian kufur kepada nikmat-nikmat Allah, dan mengingkari karunia serta kebaikan-Nya, maka ketahuilah sesungguhnya Allah Ta'ala adalah Raja segala raja dan kerajaan. Kekafiran dan kedurhakaan kalian tidak akan membahayakan-Nya, sebagaimana syukur dan ketakwaan kalian tidak akan bermanfaat bagi-Nya. Allah memerintahkan kepada kalian, dan juga kepada mereka supaya bersyukur dan bertakwa kepada-Nya, adalah karena rahmat-Nya, bukan karena Dia membutuhkan hal itu. Dan d) kemudian Allah menerangkan alasannya sebagai tambahan bagi alasan terdahulu, yaitu dengan Zat-Nya, Allah Mahakaya dari segala sesuatu; dan dengan Zat dan kesempurnaan sifat-Nya, Allah Maha Terpuji. Dia tidak membutuhkan syukur kalian untuk menyempurnakan diriNya. ${ }^{11}$

$\begin{array}{ccc}\text { Kemudian, } & \text { Ibnu } & \text { Katsir } \\ \text { menafsirkannya, } & \text { Allah } & \text { Ta'ala }\end{array}$ memberitahukan bahwa Dia adalah Pemilik langit dan bumi dan Pengatur keduanya. Oleh karena itu, Dia berfirman, Sesungguhnya Kami telah berpesan kepada orang-orang yang 
telah diberi kitab sebelum kamu dan kepada kamu sendiri, yakni Kami telah memberikan kepadamu pesan seperti yang telah Kami berikan kepada Ahli Kitab, yaitu supaya bertakwa kepada Allah Azza wa Jalla dengan cara menyembah Dia Yang Maha Esa tanpa sekutu bagi-Nya.42 Selanjutnya, Quraish Shihab menafsirkan, buktinya adalah hanya milik Allah semata, bahkan juga ciptaan dan di bawah kekuasaan dan pengaturan-Nya apa yang di langit baik makhluk yang bernyawa maupun bendabenda langit dan apa yang di bumi juga demikian. Dan sungguh Kami melalui para nabi dan kitab suci yang Allah turunkan telah mewasiatkan; berpesan kepada orang-orang yang diberi kitab suci sebelum kamu, seperti umat nabi Ibrahim, Daud, Musa, Isa, dan juga Kami wasiatkan kepada kamu wahai umat nabi Muhammad bahwa; bertakwalah kepada Allah, karena kamu bertakwa kamu akan memperoleh kebahagiaan dunia dan akhirat. 43

Kecuali itu, wacana tafsir ayat lainnya yang sering pula dijadikan wilayah dan ranah perdebatan dan diskursus dalam konteks pluralitas dan pluralisme agama adalah; Qs. Ali Imran (3) ayat 19, yang menjelaskan bahwa "Sesungguhnya agama di sisi Allah ialah Islam...",44 yang dijadikan bahan diskusi ialah, apakah yang dimaksudkan kata "Islam" itu adalah penyerahan diri (taslim) kepada Tuhan? Dan seterusnya, Qs. Ali Imran (3) ayat 85, yakni masalah siapa yang mencari agama selain Islam, dia tidak akan diterima, dan di akhirat dia termasuk orang yang rugi.45 Dalam ayat ini, diskusi panjang juga terjadi pada penafsiran dan pemahaman kata "taslim", karena kalau yang dimaksudkan "taslim" penyerahan diri berarti bukan hanya Islam agama umat Muhammad yang dimaksudkan, dan termasuk juga umat-umat ayang lainnya selain Islam dalam sejarah Muhammad. Berikutnya juga; Qs. Al-Maidah (5) ayat 72, Qs. Al-Baiyyinah (98) ayat 6, Qs. AsySyura (42) ayat 13, Qs. At-Taubah (9) ayat 30, dan lain sebagainya.

Berbagai ayat tersebut dijadikan argumentasi-bantahan dari kelompok yang anti pluralitas ataupun pluralisme untuk melakukan serangan, bahwa mereka berkesimpulan bahwa kaum pluralis dengan kemampuan mereka dalam memahami bahasa Arab yang cukup baik, maka mereka suka memelintir atau mentakwil dan mungkin menyelewengkan makna ayat sehingga kaum intelektual-awam agama percaya kepada mereka. Bila seandainya ide pluralisme agama ini diakui di dalam Islam, maka berarti tidak ada satupun orang yang dikatakan kafir, padahal dalam al-Qur'an sebutan kafir sangat banyak dijumpai.

Dalam khazanah dan wacana studi-studi keislaman ketika memahami penafsiran ayat-ayat di atas, yang selanjutnya bergulir manjadi pro dan kontra terhadap ide pluralitas dan pluralisme agama, maka setelah diuraikan secara teoritis, empiris, obyektif, akademis, dan rasional ternyata pro dan kontra tersebut dapat dijembatani pada pemahaman komprehensif tentang hakikat atau 
esensi suatu agama dan komitmen setiap umat beragama dalam menjalankan perintah-perintah ajarannya. Esensi atau hakikat dari seseorang beragama adalah, adanya upaya yang utuh dan menyeluruh untuk berserah diri, pasrah, tunduk, rekonsiliasi (taslim kepada kehendak Tuhan), dan kemudian menjadi salah satu nama agama (religion: aslamaIslam) setelah Yahudi, Kristen, dan agama-agama lain. ${ }^{46}$

Pada sisi lain, makna berserah diri, pasrah, tunduk, dan rekonsiliasi kepada Tuhan adalah "taslim" kepada Allah, bukan kepada agama terakhir manusia. Benar, bahwa Islam itu artinya berserah diri (taslim), dan agama Islam tak lain adalah agama taslim, meskipun hakikat taslim pada setiap zaman mengambil bentuk tertentu. ${ }^{47}$ Sehingga, pemahaman ini dijadikan acuan ketika membahas pluralisme agama, yang mana apapun agamanya sepanjang ajarannya sejalan dengan prinsip-prinsip taslim kepada Tuhan maka disimpulkan bahwa agama tersebut sejalan dengan "Islam". Meskipun syari'at atau cara beribadahnya berbeda-beda. Dan mereka juga akan mendapatkan pahala dari kesalehan yang sudah meraka lakukan, di dunia dan di akhirat.

Hal yang sama juga disampaikan oleh Nurcholish Madjid ketika mengulas penafsiran ayat ke 85 dari surat Ali Imran, dan barangsiapa menganut agama selain "sikap pasrah" (al-islamtaslim) itu, ia tidak akan diterima, dan di akhirat termasuk orang-orang yang merugi. Cak Nur menegaskan bahwa, beragama tanpa "sikap pasrah" kepada
Tuhan, betapapun seseorang mengaku "Muslim" atau penganut "Islam", adalah tidak benar dan "tidak bakal diterima" oleh Tuhan. ${ }^{48}$ Penjelasan Nurcholish Madjid ini, seperti juga menjadi pandangan ulama terdahulu (Ibnu Katsir pada uraian di atas) adalah relevan. Lebih dari itu, ia mempertegas---lewat pernyataannya, jadi seperti diisyaratkan dalam firman itu (Qs. $3: 85$ ), perkataan muslimin/taslim sesuai dengan makna asalnya juga menjadi "kualifikasi para pemeluk agama lain, khususnya para penganut kitab suci'---bahwa agamaagama lain pun bisa disebut Islam dan pemeluknya Muslim, manakala agama tersebut berintikan pada "kepasrahan dan tunduk patuh pada Tuhan Yang Maha Esa.

Namun, konsekuensinya, definisi Islam sebagai pasrah atau berserah-diri tidak akan menimbulkan pertentangan dengan konsep yang dikemukakan oleh ajaran Islam. Misalnya, pengertian pasrah tersebut sesuai dengan praktikpraktik wajib (ibadah ritual) yang dikenal berupa "rukun Islam". Semua ibadah ritual dalam "lima rukun Islam" menunjukkan sikap kepasrahan itu. Baik ucapan dua kalimat syahadat, shalat, puasa, zakat, dan haji adalah prilaku pasrah. Oleh karena itu, kelima ritual tersebut disebut rukun Islam, sebab kata islam-taslim selalu berarti kepasrahan. 49 Karena alasan inilah, seorang muallaf Amerika, misalnya, bisa menemukan kesadaran antara kepasrahan dari kata islam-taslim dan perwujudan dalam praktik ritual rukun Islam....Dan melalui ibadah-ibadah ritual inilah kaum 
Muslimin mengalami situasi paling personal dan langsung. Lima rukun Islam itu adalah inti kesalehan Muslim...Ibadah-ibadah ritual ini membentuk suatu jaringan seorang mukmin dengan sesamanya, dan Allah. Melalui lima rukun ini, kaum Muslim bisa mengenali secara lebih mendalam dan akrab dengan kekuasaan tidak terbatas Allah...50

Dengan demikian, terlepas dari setuju atau tidak, dalam peniscayaan pluralisme agama maka kata islamtaslim dijadikan sebagai tali penghubung bagi berbagai agama samawi yang ada di dunia. Adapun Islam faktual, yang mengandung nilai spiritual-samawi adalah Islam yang mampu mengantarkan seorang kepada hakikat taslim hati yang memberikan tempat paling luas bagi kebenaran di dalam dadanya. Sehingga dia menerima kebenaran dan mengamalkannya setelah, dari satu segi, menerimanya atas dasar penyelidikan dan analisis, dan pada segi lain, atas dasar taslim dan tidak ta'ashshub. Karenanya, sekiranya seseorang telah taslim kepada kebenaran, tetapi ia, karena sebab-sebab lain, belum sampai pada kebenaran Islam, maka orang tersebut tidak dipandang sebagai sengaja tidak mau menerima kebenaran (muqashshar), dan Allah tidak akan menyiksanya, bahkan ia termasuk orang yang selamat. ${ }^{1}$ Sebagaimana firman Allah yang berbunyi, Dan Kami tidak akan menyiksa (manusia) sebelum Kami mengutus seorang rasul (Qs. 17 : 15).52

\section{Posisi dan Kearifan Penyuluh Agama}

Secara formil posisi Penyuluh Agama adalah Pegawai Negeri Sipil (PNS) atau non PNS yang diberikan tugas, tanggung jawab, dan wewenang secara penuh oleh pejabat yang berwenang untuk melakukan kegiatan bimbingan keagamaan dan penyuluhan pembangunan kehidupan umat beragama melalui bahasa agama. ( Lihat : Keputusan Menteri Agama No. 516 Tahun 2003).

Keberadaan Penyuluh Agama (Islam) di Indonesia sejalan dengan kebutuhan Negara yang ingin mensosialisasikan program pembangunan dengan menggunakan bahasa agama, terutama pada rezim Orde Baru. Di dalam salah satu Pidato kenegaraannya pada tanggal 16 Agustus 1978, Presiden Soeharto menyatakan "semakin meningkat dan meluaskannya pembangunan, maka agama dan kepercayaan terhadap Tuhan Yang Maha Esa (YME) dari masyarakat kita harus dimasyarakatkan dalam kehidupan, baik dalam hidup seorang maupun dalam hidup sosial kemasyarakatan".53Pernyataan Presiden Soeharto tersebut menjadi legitimasi mengenai peran dan posisi strategis yang diemban penyuluh agama berikut dengan segala kearifannya untuk memahami kemajemukan bangsa Indonesia dari segi etnik, bahasa, budaya, dan agama. Sisi lainnya, pernyataan tersebut juga mengingatkan bahwa sebagian besar masyarakat Indonesia masih memandang pentingnya 
sosok ideal (seperti Penyuluh Agama) yang dapat dijadikan figur dalam kehidupan sosial keagamaan.

Penyuluh agama memiliki potensi untuk diposisikan sebagai figur dan panutan yang dianggap memiliki banyak pengetahuan keagamaan, sehingga dengan pengetahuannya itu memiliki kearifan dalam menghadapi dan menyikapi persoalan-persoalan yang timbul dari semangat dan loyalitas keagamaan masyarakat. Mengutip pandangan Antonni Giddens (2003) tentang teori "strukturasi", maka posisi dan eksistensi penyuluh agama dapat diposisikan sebagai "agen" yang dapat membentuk struktur dalam masyarakat. 54 Bisa dilihat aktifitas para penyuluh agama sebagai aktor dan fasilitator dari tindakan masyarakat beragama yang dilakukan secara berulang-ulang dan berkesinambungan dalam membangun kehidupan beragama agar sejalan dengan ajaran Tuhan. Bangunan kehidupan beragama yang dihadirkan sudah barang tentu yang memunculkan akan kesadaran berketuhanan, kesadaran kemajemukan, dan kesadaran persaudaraan antar umat beragama yang memiliki keyakinan yang berbada sebagai suatu keniscayaan.

Dengan menggunakan teori Giddens, bisa juga dicermati bahwa penyuluh agama sebagai agen akan merasionalkan tindakan mereka dalam arti mengembangkan kebiasaan seharihari yang tak hanya memberikan rasa aman kepada aktor (masyarakat tersuluh), tetapi juga memungkinkan mereka menghadapi kehidupan sosial mereka secara efisien. Artinya penyuluh agama juga punya motivasi untuk bertindak berdasarkan tugas pokok dan fungsinya (Tupoksi). Untuk menumbuhkan motivasi dalam melakukan tindakan-tindakan tersebut, penyuluh agama memerlukan seperangkat aturan yang akan menjadi acuan dan panduan dalam melakukan penyuluhan, termasuk aturan penyuluhan bagi masyarakat yang hidup dalam kemajemukan kehidupan beragama.

Pada sisi lainnya,program penyuluhan sosial keagamaan adalah sebuah proses pengubahan perilaku yang dilakukan melalui penyebarluasan informasi, komunikasi, motivasi dan edukasi mengenai kehidupaan beragama oleh penyuluh sosial keagamaan, baik secara lisan, tulisan maupun peragaan pada kelompok sasaran, sehingga muncul pemahaman yang sama, pengetahuan dan kemauan guna partisipasi secara aktif dalam pembangunan kesejahteraan sosial yang dilandasi ajaran agama.55 Penyuluhan sosial keagamaan adalah pembimbing umat beragama dalam rangka pembinaan mental, moral, dan ketaqwaan kepada Tuhan Yang Maha Esa Allah Swt., serta menjabarkan segala aspek pembangunan melalui pintu dan bahasa agama. ${ }^{6}$ Jadi penyuluhan sosial keagamaan ialah penyuluhan yang dilakukan untuk mengubah perilaku manusia (masyarakat tersuluh) yang didasari dengan nilai-nilai keagamaan untuk pembinaan mental, moral dan ketaqwaan kepada Allah Swt. untuk 
membangun masyarakat yang sejahtera, berkeadilan dan berperadaban. Menjunjung tinggi nilai-nilai pluralitas dan kemajemukan, mampu hidup berdampingan dan bekerjasama intern umat beragama, antar umat beragama, antara umat beragama dan pemerintah dalam bingkai toleransi dan kebhinnekaan.

Upaya peningkatan kualitas pembangunan agama masih dihadapkan dengan beberapa masalah dan tantangan penting, antara lain berkenaan dengan pemahaman, penghayatan, dan pengamalan ajaran agama dalam kehidupan bermasyarakat, berbangsa, dan bernegara belum seperti yang diharapkan. Ajaran agama pada masingmasing masyarakat beragama belum sepenuhnya diaktualisasikan dalam kehidupan agama secara nyata. Masih mudah dijumpai perilaku masyarakat beragama yang tidak sesuai dengan ajaran agama, seperti tindak kekerasan, sikap anarkis, lunturnya perilaku sopan santun, kurangnya rasa kasih-sayang dan saling menghargai kepada sesama umat beragama atau pun antar umat beragama. Sehingga, belum mampu diwujudkankehidupan yang harmonis antara sesama anak bangsa di dalam masyarakat beragama, yang pada gilirannya menurunkan tingkat ketentraman, kedamaian, kesejahteraan masyarakat, serta boleh jadi akan menjadi ancaman bagi keutuhan hidup dalam berbangsa dan bernegara.

Penyuluh sosial keagamaan seyogianya memiliki posisi dan peran yang sangat strategis dalam mengayomi kehidupan masyarakat beragama, karena disatu sisi tugas dan kewenangan mereka merupakan bentuk pengamalan ajaran agama (amar-makruf dan nahimungkar), dan di sisi lain dapat membantu dalam memberikan pemahaman dan pencerahan kepada masyarakat, terutama ketika terjadi silang pendapat dalam menafsirkan ayatayat (doktrin ajaran agama)yang berkaitan dengan kehidupan sosial keagamaan. Belum optimalnya peran penyuluh sosial keagamaan tersebut, boleh jadi disebabkan oleh (1) kurangnya pemahaman terhadap tugas pokok dan fungsi sebagai penyuluh sosial keagamaan. Akibatnya masyarakat menjadi ragu terhadap keberadaan dan kapasitas tenaga penyuluh agama, bahkan ada sebagian masyarakat tidak percaya pada kredibilitas penyuluh sosial keagamaan karena ketidakmampuan mereka dalam menyerap dan membahasakan bahasa agama dalam kehidupan sosial. (2) Kurangnya profesionalisme tenaga penyuluh agama, disebabkan tidak maksimalnya pelayanan yang diberikan kepada masyarakat; dan (3) kurangnya kesadaran dan kepedulian masyarakat dalam membangun atau pun menciptakan pola hidup yang sesuai dengan ajaran agama.Sehingga, ketika terjadi perbedaan dalam pemahaman dan pengamalan ajaran agama akan dengan mudah menimbulkan gesekan (titik api) yang berujung pada perpecahan.

Penyuluh sosial keagamaan sebagai pemegang peran cukup strategis 
dan berada di garda terdepan, terutama bagi masyarakat kalangan menengah ke bawah dan sebagian besar bertempat tinggal di daerah pedesaan maka kehadirannya diharapkan dapat memberikan pemikiran dan solusi atasberbagaiproblematika dan dinamika yang selalu berkembang dimasyarakat. Oleh karena itu, permasalahan penting dan mendesak yang harus menjadi prioritas kegiatan penyuluh agama adalah bagaimana cara-cara tepat dan efektif dalam meningkatkan kapasitas serta kualitas kehidupan sosial keagamaan masyarakat beragama melalui lembaga-lembaga pendidikan keagamaan (formal dan non formal) sehingga mereka mampu berperan lebih aktif dan efektif sebagai agen perubahan sosial keagamaan, khususnya bagi masyarakat yang hidup di sekitar mereka.

Perubahan yang terjadi pada masyarakat, antara lain melalui pemberdayaan lembaga pendidikan sosial keagamaan, baik pada aspek pengetahuan, sikap dan motif (niat) tindakan, dan perilaku pada akhirnya akan berimplikasi pada sikap masyarakat (umat beragama) yang lebih terbuka dalam menerima berbagai perbedaan dan problematika kehidupan yang semakin kompleks. Dengan demikian, fungsiutamapenyuluh agamabukan hanya merubah pengetahuan, sikap dan motif (niat) maupun perilaku. Akan tetapi yang lebih penting adalah mengubah sifat dan kenderungan masyarakat dari pasif, satatis, lemah dalam etos kerja dan eklusif dalam berpikir sehingga mudah terjadi konflik menjadi masyarakat yang proaktif, dinamis, harmonis dan terbuka dalam menerima perbedaan pemahaman serta mampu hidup rukun di tengah masyarakat yang plural (majemuk), sebab realitas dan keniscayaan kehidupan sosial masyarakat adalah kemajemukan (pluralitas) atau heterogenitas. Hal itu merupakan cermin peradaban manusia yang terus menerus berkembang dan mengalami perubahan menuju harmonisasi, dan hal ini pula yang menunjukkan adanya fakta sosiologis sunnatullah yang senantiasa menyertai dinamika kehidupan manusia di bumi.

Dengan demikian, kemampuan para penyuluh agama (Islam) yang memadai dalam memahami tafsir ayatayat al-Qur'an yang dijadikan argumentasi dalam menerima atau pun menolak pemikiran, paham, dan gerakan pluralitas (pluralisme) dalam kehidupan beragama, termasuk dalam menafsirkan Qs. Al-Maidah [5] : 51, Qs. An-Nisa' [4] : 144, dan yang lainnya, yang notabene menjadi polemik belakangan ini akan menampilkan kearifan tersendiri ketika menghadapi dinamika masyarakat (tersuluh) yang ikut terseret oleh "kegaduhan" penafsiran ayat tersebut. Dalam kondisi seperti itu, biasanya masyarakat beragama sangat mengharapkan pencerahan yang menyejukan dari para penyuluh agama yang memiliki kompetensi baik dan kredibelitas yang diakui oleh masyarakatnya. 


\section{Kesimpulan}

Setelah tulisan ini menguraikan sekitar wacana tafsir yang berkaitan dengan adanya kenyataan pluralitas dan pluralisme yang kemudian diidentikan dengan keberadaan dan keragaman agama, yang mana masing-masing umat meyakini adanya Tuhan dan memiliki kitab suci serta beribadah menurut keyakinan mereka masing-masing pula. Maka pada bagian akhir tulisan ini, ada beberapa catatan kesimpulan, yaitu:

Sebagai konsekuensi dari paham relativisme agama, maka doktrin dan keyakinan agama apa pun harus dinyatakan benar. Atau dengan kata lain, semua agama setidaknya bagi masingmasing pemeluknya adalah sama, karena kebenaran agama-agama walaupun berbeda-beda satu dengan lainnya, tetap harus dihargai dan "diterima”. Terlepas dari setuju atau tidak, tidak dapat dipungkiri bahwa dalam paham "pluralisme" terdapat unsur "relativisme". Yakni, tidak bisa mengklaim kepemilikan tunggal dan monopoli atas "suatu kebenaran", apalagi memaksakan kebenaran tersebut kepada pihak (agama) lain. Paling tidak, seorang pluralis akan menghindari sikap "absolutisme" yang menonjolkan keunggulannya terhadap pihak lain. Karenanya, banyak orang enggan menggunakan "pluralisme agama", karena khawatir akan terperangkap dalam lingkaran konsep "relativisme agama”.

Dalam kenyataan keragaman agama di Indonesia, maka Islam sebagai agama mayoritas sudah terbiasa dengan kemajemukan dan menerima "pluralitas agama"; yakni siap dengan kenyataan untuk hidup berdampingan dengan agama lain. Akan tetapi tidak sejalan dengan paham "pluralisme agama”, yang berpandangan bahwa semua agama sama, kebenarannya bersifat relatif, dan sama-sama berada di jalan yang sah menuju Tuhan yang sama. Maka semua agama tidak boleh mengklaim kebenaran sendiri-sendiri.

Model pluralisme yang mensyaratkan komitmen yang kokoh terhadap agama masing-masing---dalam Islam---telah dicontohkan oleh Rasulullah Saw., baik dalam tuturan maupun tindakan yang patut diteladani umat Islam dan umat agama lainnya. Hal ini terbukti, ketika beliau berhasil memimpin kemajemukan agama pada saat berada di Medinah, sehingga terwujud masyarakat Madani melalui Piagam Madinah.

Pada dasarnya wacana tafsir memberikan posisi tawar dan netral dalam masalah pluralitas maupun pluralisme agama, benang lurus yang dibentangkan ialah adanya pengakuan penyerahan diri (taslim), tunduk, patuh, dan rekonsiliasi kepada kehendak Tuhan. Posisi ini boleh ditempati oleh agama manapun; Islam, Yahudi, Nasrani, Sabi'in, dan lain-lain, sepanjang mereka melakukan kesalehan-kesalehan yang dilandasi taslim kepada Tuhan maka mereka berhak mendapatkan pahala di dunia dan di akhirat. Dan tidak boleh terjadi "pemaksaan" dalam mencari dan menuju kedamaian (taslim) yang menjadi hakikat semua agama, karena 
dalil-dalil dan hujjah masing-masing sudah jelas dan terang benderang.

Al-Qur'an sebagai kitab suci agama taslim, telahmengajarkan bahwa orientasi ajarannya ialah berusaha kepada terciptanya persatuan, kesetaraan, kedamaian, dan ketenteraman dengan adanya kesadaran kemajemukan agama dan umat beragama (Qs. Al-Hujurat [49] : 13).57 Agar tercipta jalinan kemajemukan tersebut, al-Qur'an menawarkan titiktitik temu yang dinamakan "kalimatun sawa"; suatu ketetapan yang tidak akan terjadi perselisihan dan pertengkaran antar umat beragama. (Qs. Ali Imran [3] :64).58

Penyuluh agama yang mengisi tugas kegiatan penyuluhan sosial keagamaan, khususnya bagi masyarakat beragama Islam di Indonesia, memiliki posisi strategis dan berada di garda terdepan dalam memberikan bimbingan, pembinaan, penyuluhan, dan pendampingan bagi kehidupan beragama pada masyarakat. Maka penyuluh agama seyogianya memiliki pengetahuan yang memadai mengenai persoalan-persoalan keagamaan, mampu menempatkan dirinya sebagai suri tauladan (uswah) dalam pengamalan ajaran agama, dan memiliki kearifan yang tinggi dalam menyikapi dinamika keberagaman masyarakat beragama, terutama ketika dihadapkan kepada perbedaan pemahaman dalam menafsirkan bahasabahasa agama yang dapat memicu kompliks intern umat beragama, antar umat beragama, antara umat beragama dan pemerintah.

\section{Catatan kaki:}

${ }^{1}$ Fatwa MUI nomor 7/MUNAS VII/MUI/II/2005, tanggal 29 Juli 2005 tentang Pluralisme, Liberalisme, dan Sekularisme agama. Menetapkan bahwa paham Pluralisme agama adalah paham yang bertentangan dengan ajaran Islam.

${ }^{2}$ Nurcholish Madjid, Islam, Doktrin dan Peradaban: Sebuah Telaah Kritis tentang Masalah Keimanan, Kemanusiaan, dan Kemodernan, (Jakarta: Paramadina, 1992), h. 8.

${ }^{3}$ Soerjono Soekanto, Sosiologi Suatu Pengantar, (Jakarta: PT. RajaGrafindo Persada, 2004), cet. ke-37, h. 117.

${ }^{4}$ Soerjono Soekanto, Sosiologi Suatu Pengantar, h. 119.

${ }^{5}$ Gerungan, Psikologi Sosial, (Bandung: PT. Eresco, 1991), cet. ke-12, h. 21-22.

${ }^{6}$ Gerungan, Psikologi Sosial, h. 23.

${ }^{7}$ Gerungan, Psikologi Sosial, h. 24.

${ }^{8}$ Gerungan, Psikologi Sosial, h. 26.

${ }^{9}$ Gerungan, Psikologi Sosial, h. 27.

${ }^{10}$ Syekh Muhammad Abduh, Risalah Tauhid, terj. KH. Firdaus A.N., (Jakarta: Bulan Bintang, 1979), cet. ke-7, h. 161-162.

${ }^{11} \mathrm{Abu}$ Khalid Resa Gunarsa, Pluralisme Agama: Trend Pemikiran Semua Agama adalah Sama, diakses dari https://muslim.or.id/9474, tanggal 15 Pebruari 2016, h. 2.

${ }^{12} \mathrm{Abu}$ Khalid Resa Gunarsa, Pluralisme Agama: Trend Pemikiran Semua Agama adalah Sama, diakses dari https://muslim.or.id/9474, tanggal 15 Pebruari 2016, h. 3.

${ }^{13}$ Riaz Hassan, Keragaman Iman: Studi Komparatif Masyarakat Muslim, (Jakarta: PT. RajaGrafindo Persada, 2006), cet. ke-1, 13.

${ }^{14}$ Riaz Hassan, Keragaman Iman: Studi Komparatif Masyarakat Muslim, h. 15-16.

${ }^{15}$ Fatwa MUI nomor 7/MUNAS VII/MUI/II/2005, tanggal 29 Juli 2005 tentang Pluralisme, Liberalisme, dan Sekularisme agama. Menetapkan bahwa paham Pluralisme agama adalah paham yang bertentangan dengan ajaran Islam.

${ }^{16}$ Abah Zaky, Pluralisme Agama dalam Pandangan Islam, diakses dari: https://www.muslimdaily.net//artikel studi islam, tanggal 15 Pebruari 2016, jam 11:37, h. 3.

${ }^{17}$ Murtadha Muthahhari, Perspektif Al-Quran tentang Manusia dan Agama, (Bandung: Mizan, 1997), cet. ke-9, h. 18-19. 
${ }^{18}$ Murtadha Muthahhari, Keadilan Ilahi: Asas Pandangan-Dunia Islam, (Bandung: Mizan, 1997), cet. ke-3, h. 224.

${ }^{19}$ Murtadha Muthahhari, Keadilan Ilahi: Asas Pandangan-Dunia Islam, h. 229.

${ }^{20}$ Departemen Agama RI., Al-Qur'an dan Terjemahnya, (Jakarta: CV. Naladana, 2004), cet. ke-1, h. 76.

${ }^{21}$ Murtadha Muthahhari, Keadilan Ilahi: Asas Pandangan-Dunia Islam, h. 231-232.

${ }^{22}$ Departemen Agama RI., Al-Qur'an dan Terjemahnya, h. 190.

${ }^{23}$ Adian Husaini, Pluralisme dalam Pandangan Agama, diakses dari: http://www.kompasiana.com. Tanggal 15 Pebruari 2016, jam 10:52, h. 2.

${ }^{24}$ Fatwa MUI nomor 7/MUNAS VII/MUI/II/2005, tanggal 29 Juli 2005 tentang Pluralisme, Liberalisme, dan Sekularisme agama. Menetapkan bahwa paham Pluralisme agama adalah paham yang bertentangan dengan ajaran Islam.

${ }^{25}$ Nurcholish Madjid, Islam, Doktrin dan Peradaban: Sebuah Telaah Kritis tentang Masalah Keimanan, Kemanusiaan, dan Kemodernan, h. 14.

${ }^{26}$ Tarmizi Taher, et.al., Radikalisme Agama, (Jakarta; PPIM-IAIN, 1998), cet. ke-1, 104-106.

${ }^{27}$ Tarmizi Taher, et.al., Radikalisme Agama, h. 7.

${ }^{28}$ Departemen Agama RI., Al-Qur'an dan Terjemahnya, h. 53.

${ }^{29}$ Sesungguhnya kewajibanmu adalah menyajikan Islam melalui keyakinan Islam yang "toleran", member petunjuk, dan menunjukkan manusia. Dan tugas manusia merenungkan akidah itu, menelaah dalil-dalil, hujah-hujah, dan argumentasinya yang merupakan konsepsi sempurna dan tidak mengandung keraguan.

${ }^{30}$ Muhammad Nasib ar-Rifa'i, Kemudahan dari Allah: Ringkasan Tafsir Ibnu Katsir, (Jakarta: Gema Insani, 2014), jilid 1, cet. ke-3, h. 324.

${ }^{31}$ Ahmad Mushthafa Al-Maraghi, Terjemah Tafsir Al-Maraghi, terj. Bahrun Abubakar, (Semarang: PT. Karya Toha Putra, 1993), jilid 3, cet. ke-2, h. 31.

${ }^{32}$ M. Quraish Shihab, Tafsir Al-Mishbah: Pesan, Kesan dan Keserasian Al-Qur'an, (Jakarta: Lentera Hati, 2007), volume 1, cet. ke11, h. 551-552.

${ }^{33}$ Departemen Agama RI., Al-Qur'an dan Terjemahnya, h. 12.
${ }^{34}$ M. Quraish Shihab, Tafsir Al-Mishbah: Pesan, Kesan dan Keserasian Al-Qur'an, volume 1, h. 214.

${ }^{35}$ Ahmad Mushthafa Al-Maraghi, Terjemah Tafsir Al-Maraghi, jilid 1, h. 237.

${ }^{36} \mathrm{Ibnu}$ Katsir berpendapat bahwa yag dimaksud di sini adalah; baik ia orang yang beriman kepada Muhammad setelah beliau diutus atau pun orang yang beriman kepadanya sebelum beliau diutus. Seperti Qis bin Sa'idah al-Ayadi, Zaid bin Umar bin Nufail, Waraqah bin Naufal, Barra' asySyinni, Abu Dzar al-Ghifari, Salman al-Farisi, Pendeta Buhaira, dan delegasi Najasyi.

${ }^{37}$ Ibnu Katsir menyatakan bahwa Yahudi dan Nasrani---sebagaimana telah dimaklumi---adalah dua umat yang bernisbat kepada nabi Musa as. dan Isa as. Kedua nama ini melekat pada Yahudi dan Nasrani pada zaman Musa dan Isa, yaitu ketika mereka masih memegang teguh kebenaran. Kedua nama it uterus melekat, seperti melekatnya nama Islam bagi umat Muhammad. Adapun mengenai Shabi'in, maka terjadi ikhtilaf di kalangan mufassir. Ada yang berpendapat bahwa mereka adalah sesuatu yang mengikut fitrahnya. Mereka tidak memiliki agama yang ditetapkan yang harus diikuti. Oleh karena itu, kaum musyrikin menggelari mereka yang masuk Islam dengan shabi'i, yang berarti keluar dari agamaagama yang lain. Sementara itu, ulama lain mengatakan bahwa mereka dinami Shabi'in sebab mereka keluar dari agama Yahudi, lalu menyembah malaikat dan bintang-bintang. Menurut Ibnu Tamiyah, pendapat yang terakhir ini yang paling sahih (Baca kitabnya: Bantahan terhadap Para Ahli Logika).

${ }^{38}$ Muhammad Nasib ar-Rifa'i, Kemudahan dari Allah: Ringkasan Tafsir Ibnu Katsir, jilid 1, h. 115.

${ }^{39}$ Departemen Agama RI., Al-Qur'an dan Terjemahnya, h. 130.

${ }^{40}$ Ahmad Mushthafa Al-Maraghi, Terjemah Tafsir Al-Maraghi, jilid 5, h. 293.

${ }^{41}$ Ahmad Mushthafa Al-Maraghi, Terjemah Tafsir Al-Maraghi, jilid 5, h. 294.

${ }^{42}$ Muhammad Nasib ar-Rifa'i, Kemudahan dari Allah: Ringkasan Tafsir Ibnu Katsir, jilid 1, h. 614.

${ }^{43}$ M. Quraish Shihab, Tafsir Al-Mishbah: Pesan, Kesan dan Keserasian Al-Qur'an, volume 2, h. 609.

${ }^{44}$ Departemen Agama RI., Al-Qur'an dan Terjemahnya, h. 65.

${ }^{45}$ Departemen Agama RI., Al-Qur'an dan Terjemahnya, h. 76. 
${ }^{46}$ Hans Wehr, Mu'jam al-Allugha al-'Arabiyya al-Mu'ashira, J. Milton Cowan (ed.), (London: Macdonald \& Evans Ltd., 1980), h. 426.

${ }^{47}$ Murtadha Muthahhari, Keadilan Ilahi: Asas Pandangan-Dunia Islam, h. 231.

${ }^{48}$ Nurcholish Madjid, Islam, Doktrin dan Peradaban; Sebuah Telaah Kritis tentang Masalah Keimanan, Kemanusiaan, dan Kemodernan, h. 9-10.

${ }^{49}$ Mulyadhi Kartanegara (ed.), Pengantar Studi Islam, (Jakarta: UIN Press, 2010), cet. ke-1, 32.

${ }^{50}$ Jeffrey Lang, Bahkan Malaikat pun Bertanya, terj. Abdullah Ali (Jakarta: Serambi, 2000), h. 210-211.

${ }^{51}$ Murtadha Muthahhari, Keadilan Ilahi: Asas Pandangan-Dunia Islam, h. 244.

${ }^{52}$ Departemen Agama RI., Al-Qur'an dan Terjemahnya, h. 386.

${ }^{53}$ Muzayyin Arifin, Pokok-Pokok Pikiran tentang Bimbingan dan Penyuluhan Agama, (Jakarta: Bulan Bintang, 1976), h. 11.

${ }^{54}$ Kustini, Mencari Format Ideal Pemberdayaan Penyuluh Agama dalam Peningkatan Pelayanan Keagamaan, (Jakarta: Puslitbang Kehidupan Keagamaan, 2014), h. xiii.

55 Puji Mulyani, 2014, Ilmu Pekerjaan Sosial, diakses pada tanggal 20 Mei 2016 jam 20.32 WIB, dari http://pujimulyanie.blogspot.co.id/2014/05/penyul uhan-sosial.html?m=1.

${ }^{56}$ Nurul Fazrin, 2013, Tugas, Peran dan Fungsi Penyuluhan Agama Islam, diakses pada tanggal 20 Mei 2016 jam 21.00 WIB, dari http://nurulfazrin91.blogspot.co.id/2013/03/tugasperan-dan-fungsi-a.html?m=1.

${ }^{57}$ Departemen Agama RI., Al-Qur'an dan Terjemahnya, h. 745 .

${ }^{58}$ Departemen Agama RI., Al-Qur'an dan Terjemahnya, h. 72 .

\section{DAFTAR PUSTAKA}

Abduh, Syekh Muhammad, Risalah Tauhid, terj. KH. Firdaus A.N., Jakarta: Bulan Bintang, 1979, cet. ke7.

Arifin, Muzayyin, Pokok-Pokok Pikiran tentang Bimbingan dan Penyuluhan Agama, Jakarta: Bulan Bintang, 1976.

Kustini, Mencari Format Ideal Pemberdayaan Penyuluh Agama dalam
Peningkatan Pelayanan Keagamaan,

Jakarta: Puslitbang Kehidupan

Keagamaan, 2014.

Al-Maraghi, Ahmad Mushthafa, Terjemah Tafsir Al-Maraghi, terj. Bahrun Abubakar, Semarang: PT. Karya Toha Putra, 1993, jilid 1-3.

Al-Munawar, Said Aqil Husein, Fikih

Hubungan Antar Agama, Ciputat: PT.

Ciputat Press, 2005.

Ar-Rifa'i, Muhammad Nasib,

Kemudahan dari Allah: Ringkasan

Tafsir Ibnu Katsir, Jakarta: Gema

Insani, 2014, jilid 1, cet. ke-3.

Departemen Agama RI., Al-Qur'an dan Terjemahnya, Jakarta: CV. Naladana, 2004, cet. ke-1.

Gerungan, Psikologi Sosial, Bandung: PT. Eresco, 1991, cet. ke-12.

Hassan, Riaz, Keragaman Iman: Studi Komparatif Masyarakat Muslim, Jakarta: PT. RajaGrafindo Persada, 2006, cet. ke-1.

Ismail, Faisal, Islam Idealitas Ilahiyah dan Realitas Insaniyah, Yogyakarta: PT. Tiara Wacana, 1999.

Kartanegara, Mulyadhi (ed.), Pengantar Studi Islam, Jakarta: UIN Press, 2010, cet. ke-1.

Kritter, Paul F., Satu Bumi Banyak Agama, Jakarta: PT. BPK Gunung Mulia, 1995.

Lang, Jeffrey, Bahkan Malaikat pun Bertanya, terj. Abdullah Ali Jakarta: Serambi, 2000.

Madjid, Nurcholish, Islam, Doktrin dan Peradaban: Sebuah Telaah Kritis tentang Masalah Keimanan, Kemanusiaan, dan Kemodernan, Jakarta: Paramadina, 1992. 
Murtadha Muthahhari, Keadilan Ilahi: Asas Pandangan-Dunia Islam, Bandung: Mizan, 1997, cet. ke-3.

Quran tentang Manusia dan Agama, Bandung: Mizan, 1997, cet. ke-9.

Wehr, Hans, Mu'jam al-Allugha al'Arabiyya al-Mu'ashira, J. Milton Cowan (ed.), London: Macdonald \& Evans Ltd., 1980.

Shihab, M. Quraish, Tafsir Al-Mishbah: Pesan, Kesan dan Keserasian AlQur'an, Jakarta: Lentera Hati, 2007, volume 1-2, cet. ke-11.

Taher, Tarmizi, et.al., Radikalisme Agama, Jakarta; PPIM-IAIN, 1998, cet. ke-1.

Soekanto, Soerjono, Sosiologi Suatu Pengantar, Jakarta: PT. RajaGrafindo Persada, 2004, cet. ke-37.

Yatim, Badri, Sejarah Peradaban Islam, Jakarta: Logos, 2003.

Internet:

Abah Zaky, Pluralisme Agama dalam Pandangan Islam, diakses dari: https://www.muslimdaily.net//artikel studi islam, tanggal 15 Pebruari 2016, jam 11:37.

Abu Khalid Resa Gunarsa, Pluralisme Agama: Trend Pemikiran Semua Agama adalah Sama, diakses dari https://muslim.or.id/9474, tanggal 15 Pebruari 2016.

Adian Husaini, Pluralisme dalam Pandangan Agama, diakses dari: http://www.kompasiana.com. Tanggal 15 Pebruari 2016, jam 10:52.

Nurul Fazrin, 2013, Tugas, Peran dan Fungsi Penyuluhan Agama Islam, diakses pada tanggal 20 Mei 2016 jam 21.00

WIB, http://nurulfazrin91.blogspot.co.id/201

3/03/tugas-peran-dan-fungsi-

a.html? $\mathrm{m}=1$.

Puji Mulyani, 2014, Ilmu Pekerjaan Sosial, diakses pada tanggal 20 Mei 2016 jam 20.32 WIB, dari http://pujimulyanie.blogspot.co.id/201 4/05/penyuluhan-sosial.html? $\mathrm{m}=1$.

Buku UUD 1945, P-4, dan GBHN, dalam TAP MPR Nomor II/MPR, tahun 1983.

Fatwa MUI nomor 7/MUNAS VII/MUI/II/2005, tanggal 29 Juli 2005 tentang Pluralisme, Liberalisme, dan Sekularisme agama. Menetapkan bahwa paham Pluralisme agama adalah paham yang bertentangan dengan ajaran Islam.

Buku UUD 1945, P-4, dan GBHN, dalam TAP MPR Nomor II/MPR, tahun 1983.

Tentang Penulis:

M. Lutfi: Pengajar UIN Syarif Hidayatullah Jakarta 